\title{
ANALISIS KEPUTUSAN KONSUMEN TERHADAP PEMBELIAN AYAM GORENG (STUDI KASUS PERUSAHAN X DI KABUPATEN JEMBER)
}

\author{
Influence Analysis on Customer Buying Decision of fried chicken in X Company (Study Case \\ in X Company of Jember)
}

\author{
Hariadi Subagja ${ }^{1}$, Estin Roso Pristiwaningsih ${ }^{2}$, Joko Irsan Sanyoto ${ }^{1}$, Agus Hadi Prayitno ${ }^{1}$ \\ ${ }^{1}$ Jurusan Perternakan, Politeknik Negeri Jember \\ 2Manajemen Bisnis Unggas, Politeknik Negeri Jember \\ Email: hariadisubagja@gmail.com
}

\section{INTISARI}

Penelitian ini bertujuan untuk mengetahui keputusan pembelian produk ayam goreng dan mengetahui faktor dominan yang mempengaruhi keputusan pembelian di perusahaan X. Penelitian diakukan di dua tempat yang berbeda yaitu di jalan Gajah Mada nomor 74 dan Roxy Square yang terletak di jalan Hayam Wuruk Kabupaten Jember. Metode penelitian yang digunakan adalah survei dengan 75 responden yang diambil menggunakan teknik purposive sampling. Data hasil penelitian diolah menggunakan analisis regresi linier berganda, uji $\mathrm{F}$, dan uji t. Hasil analisis menunjukkan persamaan $Y=3,040-0,103 X_{1}+0,473 X_{2}+0,060 X_{3}+0,133 X_{4}+$ $1,170 \mathrm{X}_{5}$. Persamaan tersebut berarti setiap besaran keputusan pembelian dipengaruhi oleh $\mathrm{X}_{1}$ (harga) sebesar - 0,103, $\mathrm{X}_{2}$ (cita rasa) sebesar 0,473, $\mathrm{X}_{3}$ (promosi) sebesar 0,060, $\mathrm{X}_{4}$ (gaya hidup) sebesar 0,133 , dan $X_{5}$ (desain interior) sebesar 1,170. Hasil uji $F$ menunjukkan secara bersamasama semua variabel signifikan $(\mathrm{P}>0,05)$ terhadap keputusan pembelian di perusahaan $\mathrm{X}$.

Kata kunci: Harga, Cita Rasa, Promosi, Gaya Hidup, Desain Interior, Keputusan Pembelian

\begin{abstract}
This research aimed to know consider of consumer to decide of buying fried chicken and to know the dominan factor what it influence of buying decision in $x$ company. The research was conducted at the two outlets, they were Gajah Mada street Number 74 dan Roxy Square Hayam wuruk street, Jember. The research method used was survey wtih 75 respondents that took by purposive sampling. The data result were analyzed using multiple linear regression analysis, $F$-test, and $t$ test. The result of analysis showed $Y=3,040-0,103 X 1+0,473 X 2+0,060 X 3+0,133 X 4+1,170 X 5$. That equation means every level of consumer buying decision by X1 (price) equal to -0,103, X2 (taste) equal to 0,473, X3 (promotion) equal to 0,060, X4 (life style) equal to 0,133, and X5 (desain interior) equal to 1,170. The result of F-test showed that all of variabels has significant.
\end{abstract}

Keywords: Price, Taste, Promotion, Lifestyle, Desain Interior, Cunsomer Buying Decision

\section{PENDAHULUAN}

Daging ayam merupakan salah satu produk peternakan unggas yang dibutuhkan untuk memenuhi kebutuhan protein hewani. Salah satu penghasil daging yang digemari masyarakat Indonesia adalah daging ayam ras pedaging (broiler). Menurut data dari Kementerian Pertanian pada tahun 2015 Indonesia menghasilkan 1.627.106 ton produksi daging broiler. Hasil produksi daging broiler sebagian besar diolah dalam bentuk ayam goreng, dan lainnya dalam bentuk yang berbeda sesuai permintaan masyarakat. Ayam goreng dengan penambahan tepung dapat dijumpai pada tempat makan seperti Kentucky Fried Chicken (KFC), C'Best, California Fried Chicken (CFC), dan fried chicken yang masih berpotensi lokal. Pertimbangan konsumen dalam memilih dan membuat keputusan 
pembelian untuk suatu produk sangat bervariasi menurut kebutuhan masing masing. Kotler (2008) menyatakan bahwa kebutuhan manusia tidak saja dipengaruhi oleh motivasinya melainkan juga hal-hal eksternal seperti budaya, sosial dan ekonomi. Faktor-faktor yang mempengaruhi perilaku konsumen dalam memilih produk sebagai kebutuhan ialah faktor kebudayaan, sosial, pribadi, dan psikologis (Simamora, 2001).

Produk ayam goreng menjadi pusat penelitian sebagai preferensi konsumen. Salah satu produk ayam goreng yang akan diteliti menurut aspek pertimbangan konsumen adalah produk yang dihasilkan oleh perusahaan X. Perusahaan X merupakan perusahaan restoran fast food yang memiliki gerai terbanyak di Indonesia (SWA, 2014). Pertimbangan konsumen akan perusahaan $\mathrm{X}$ merupakan skema yang meliputi beberapa atribut yaitu renyah, cepat saji, bersih, dan murah. Pertimbangan itu memungkinkan adanya evaluasi positif terhadap perusahaan $\mathrm{X}$ dan memungkinkan konsumen untuk makan di perusahaan $\mathrm{X}$.

Perusahaan X di Kabupaten Jember memiliki dua gerai yaitu di jalan Gajah Mada No 74 dan Roxy Square jalan Hayam wuruk yang akan dijadikan sebagai subyek penelitian. Transaksi penjualan perusahaan X di Kabupaten Jember rata-rata mencapai 400 transaksi per harinya. Hasil transaksi menunjukkan bahwa konsumen sering membeli dan melakukan keputusan pembelian terhadap produk ayam goreng di perusahan $\mathrm{X}$, sehingga dilakukan penelitian untuk menganalisis keputusan konsumen terhadap pembelian ayam goreng perusahaan $\mathrm{X}$. Hasil analisis akan diketahui alasan-alasan konsumen dalam memilih ayam goreng perusahaan X.

\section{MATERI DAN METODE}

\section{Rancangan Penelitian}

Penelitian ini merupakan jenis penelitian yang menggunakan pendekatan deskriptif kuantitatif. Rancangan penelitian dilakukan menggunakan metode survei. Metode survei dilakukan untuk mengumpulkan data informasi dari responden melalui pengisian kuisioner.

\section{Populasi Penelitian dan Teknik Pengambilan Sampel}

Populasi dalam penelitian ini konsumen yang membeli ayam goreng di perusahaan $\mathrm{X}$ sebanyak 75 orang mengacu pada metode Sugiyono (2014). Penelitian ini dilakukan menggunakan metode sampling menurut Usman dan Akbar (2000) dengan responden yaitu konsumen produk ayam goreng perusahan X. Konsumen yang menjadi responden berkriteria sebagai berikut:

1. Pelanggan yang membeli minimal sekali ayam goreng perusahan $\mathrm{X}$ dalam seminggu.

2. Pelanggan usia minimal 19 tahun.

\section{Variabel Penelitian}

Variabel dalam penelitian meliputi variabel terikat (dependent) yaitu keputusan pembelian dan variabel tidak terikat (independent) yaitu: harga, cita rasa, promosi, gaya hidup, dan desain interior.

\section{Instrumen Penelitian}

Alat yang digunakan dalam pengumpulan data pada penelitian ini adalah kuisoner. Kuisoner yang dibuat untuk menggali data yang kemudian dilakukan analisis data pada keputusan pembelian produk ayam goreng di perusahaan $\mathrm{X}$ Kabupaten Jember. Kuesioner menggunakan skala likert yang terdiri dari sangat setuju(5), setuju (4), cukup setuju (3), tidak setuju (2), dan sangat tidak setuju (1)

\section{Analisis Data}

Analisis regresi linear berganda digunakan dengan tujuan mencari hubungan dua variabel bebas atau lebih $(\mathrm{X})$ yang secara bersama-sama dihubungkan pada variabel terikat (Y) (Usman dan Akbar, 2000). 
Persamaan regresi untuk enam prediktor adalah:

$\mathrm{Y}=\alpha+\mathrm{b}_{1} \mathrm{X}_{1}+\mathrm{b}_{2} \mathrm{X}_{2}+\mathrm{b}_{3} \mathrm{X}_{3}+\mathrm{b}_{4} \mathrm{X}_{4}+\mathrm{b}_{5} \mathrm{X}_{5}+e$

Keterangan:

$\mathrm{Y}=$ keputusan pembelian

$\mathrm{a}=$ Konstanta

$\mathrm{b}=$ koefisien dari variabel bebas

$\mathrm{X}_{1}=$ harga

$\mathrm{X}_{2}=$ cita rasa

$\mathrm{X}_{3}=$ promosi

$\mathrm{X}_{4}=$ gaya hidup

$\mathrm{X}_{5}=$ desain interior

$e=$ Standar error

Uji determinasi ditentukan oleh koefisien determinasi $\left(\mathrm{R}^{2}\right)$ untuk menghitung seberapa besar persentase variabel dependen yang disebabkan oleh faktor perubahan variabel bebas. Variabel-variabel yang diteliti yaitu harga, cita rasa, promosi, gaya hidup, dan display interior. Nilai koefisien $\mathrm{R}^{2}$ paling besar
1 dan paling kecil $0(0<R 2<1)$. Bila $\mathrm{R}^{2}$ sama dengan 0 maka garis regresi tidak dapat digunakan untuk membuat ramalan variabel dependen, sebab variabel-variabel yang dimaksudkan kedalam persamaan regresi tidak mempunyai pengaruh varian variabel dependen. Semakin dekat $\mathrm{R}^{2}$ dengan 1 , maka semakin tepat regresi untuk meramalkan variabel dependen, dan menunjukkan kondisi yang sebenarnya dalam penelitian.

Uji F menggunakan statistical package for the social sciences (SPSS) versi 16. Rumus yang digunakan untuk uji F yaitu:

$$
F=\frac{R^{2}: k}{\left(1-R^{2}\right):(n-k-1)}
$$

\section{Keterangan:}

$\mathrm{F}$ = pengujian secara serempak

$\mathrm{R}^{2}=$ koefisien determinasi berganda

$\mathrm{k}$ = banyaknya variabel

$\mathrm{n}$ = banyaknya sampel

Tabel 1. Hasil Uji koefisien determinasi $\left(\mathrm{R}^{2}\right)$

\begin{tabular}{ccccc}
\hline Model & $R$ & $R$ Square & $\begin{array}{c}\text { Adjusted } R \\
\text { Square }\end{array}$ & $\begin{array}{c}\text { Std. Error of the } \\
\text { Estimate }\end{array}$ \\
\hline 1 & $.883^{\mathrm{a}}$ & .780 & .764 & 1.35378 \\
\hline
\end{tabular}

\section{HASIL DAN PEMBAHASAN}

\section{Analisis Regresi Linear Berganda}

Hasil perhitungan analisis regresi linear berganda yang menunjukkan hubungan $\mathrm{X}$ dan Y disajikan pada Tabel 2., dan diperoleh persamaan regresi linear berganda yaitu $Y=$ $3,040-0,103 X_{1}+0,473 X_{2}+0,060 X_{3}+0,133 X_{4}$ $+1,170 \mathrm{X}_{5}$.

\section{Koefisien Determinasi}

Analisis koefisien determinasi dengan variabel bebas yaitu keputusan pembelian (Y) dapat dilihat pada Tabel 1. Hasil pengujian diatas menunjukkan koefisien determinasi $R$ Square sebesar 0,780 atau $78,0 \%$. Hal ini berarti sebesar 78,0\% variasi dari keputusan pembelian (Y) disebabkan oleh faktor-faktor perubahan variabel harga $\left(\mathrm{X}_{1}\right)$, cita rasa $\left(\mathrm{X}_{2}\right)$, promosi $\left(\mathrm{X}_{3}\right)$, gaya hidup $\left(\mathrm{X}_{4}\right)$, interior display $\left(\mathrm{X}_{5}\right)$. Sedangkan $22 \%$ dapat dijelaskan oleh sebab-sebab lainnya diluar model variabel yang digunakan dalam penelitian ini.

\section{Uji F}

Hasil analisis uji $\mathrm{F}$ diperoleh variabel harga, cita rasa, promosi, gaya hidup, dan desain interior memiliki pengaruh secara signifikan terhadap keputusan pembelian seperti yang disajikan pada Tabel 3 .

Harga tidak membuat konsumen beralih dan membeli produk lain. Produk ayam goreng perusahan $\mathrm{X}$ dinilai memiliki harga sesuai dengan harapan konsumen. Nilasari et al. (2012) menyatakan bahwa harga produk mahal tetapi manfaat yang didapat konsumen sesuai atau sebanding maka konsumen akan tetap membeli. 
Tabel 2. Hasil analisis regresi linear berganda

\begin{tabular}{|c|c|c|c|c|c|}
\hline \multirow[t]{2}{*}{ Model } & \multicolumn{2}{|c|}{ Unstandardized Coefficients } & \multirow{2}{*}{$\begin{array}{c}\text { Standardized } \\
\text { Coefficients }\end{array}$} & \multirow{2}{*}{$t$} & \multirow{2}{*}{ Sig. } \\
\hline & $B$ & Std. Error & & & \\
\hline (Constant) & 3.040 & 1.014 & & 2.997 & .004 \\
\hline Harga $\left(X_{1}\right)$ & -.103 & .120 & -.072 & -.864 & .390 \\
\hline Cita Rasa $\left(\mathrm{X}_{2}\right)$ & .473 & .153 & .264 & 3.101 & .003 \\
\hline Promosi $\left(\mathrm{X}_{3}\right)$ & .060 & .126 & .039 & .479 & .634 \\
\hline Gaya Hidup $\left(\mathrm{X}_{4}\right)$ & .133 & .136 & .080 & .973 & .334 \\
\hline Desain interior $\left(\mathrm{X}_{5}\right)$ & 1.170 & .225 & .638 & 5.198 & .000 \\
\hline
\end{tabular}

Perusahaan $\mathrm{X}$ memiliki cita rasa yang khas, terjaga kebersihannya, dan konsisten. Cita rasa didapatkan dengan cara menjalankan semua kegiatan prosedur yang telah ditetapkan oleh PT Fast Food Indonesia Tbk. Rasa merupakan faktor yang sering menjadi bahan evaluasi untuk mengetahui produk mana yang sesuai dengan tingkat kesukaan konsumen. Konsumen yang tidak puas terhadap rasa suatu produk akan kecewa dan tidak akan membeli produk tersebut kembali, sedangkan konsumen yang puas akan melakukan pembelian terus-menerus (Rahardjo, 2016).

Promosi yang dilakukan oleh perusahaan X di Kabupaten Jember dapat menginformasikan apa yang menjadi kebutuhan konsumen Kabupaten Jember melalui periklanan. Ketika produk ayam goreng menjadi sebuah kebutuhan ataupun keinginan, promosi mengenai hal-hal terbaru dari perusahaan $\mathrm{X}$ sangat dibutuhkan oleh konsumen untuk melakukan keputusan pembelian. Produk ayam goreng perusahaan X di Jember merupakan suatu produk yang dipertimbangkan karena memiliki merek yang terkenal di dunia. Rani (2014) menyatakan bahwa gaya hidup terlihat dari cara seseorang hidup di lingkungan sosial dan mengekspesikan suatu benda di sekitarnya. Ayam goreng perusahaan $\mathrm{X}$ menjadi pertimbangan untuk konsumen Kabupaten Jember, karena produk yang memiliki merek mendunia.

Tabel 3. Hasil uji F

\begin{tabular}{cccccc}
\hline Model & Sum of Squares & $d f$ & Mean Square & $F$ & Sig \\
\hline Regression & 448.208 & 5 & 89.642 & 48.912 & $.000^{\mathrm{a}}$ \\
Residual & 126.458 & 69 & 1.833 & & \\
\hline Total & 574.667 & 74 & & & \\
\hline
\end{tabular}

\section{Uji t}

Hasil analisis uji $\mathrm{t}$ diperoleh masingmasing variabel harga, promosi, dan gaya hidup, tidak berpengaruh terhadap keputusan pembelian produk ayam goreng di perusahaan $X$. Variabel cita rasa dan desain interior memiliki pengaruh secara signifikan terhadap keputusan pembelian seperti yang disajikan pada Tabel 4.

Cita rasa khas, konsistensi dari produk, dan terjaganya mutu produk ayam goreng di perusahaan $\mathrm{X}$ dapat meningkatkan keputusan pembelian. Rasa ayam goreng perusahan $\mathrm{X}$ sangat disukai oleh konsumen dikarenakan rasa yang dimiliki mengikuti selera konsumen. Hasil analisis yang telah dilakukan sejalan dengan penelitian Dien et al. (2016) yaitu kualitas produk meliputi cita rasa, kebersihan, dan rasa yang konsisten merupakan salah satu syarat dalam membuat keputusan pembelian.

Desain interior perusahan $\mathrm{X}$ memiliki tata letak yang berbeda yaitu: terdapat tempat bermain untuk anak-anak, design unik, tempat luas, dan dilengkapi dengan air conditioner untuk meningkatkan kenyamanan konsumen. Konsumen melakukan keputusan pembelian 
dengan desain interior standar diberikan oleh perusahan $X$. konsumen membeli suatu produk tidak hanya karena rasa, harga, gaya hidup dan promosi, melainkan faktor tempat dapat menjadi pertimbangan konsumen untuk menginginkan suatu produk (Kotler, 2008).Hasil analisis diatas memiliki persamaan pendapat dengan penelitian
Kusherawati et al. (2015) yang menyatakan bahwa tata letak desain interior mempengaruhi keputusan pembelian di perusahan X Bandung. Setiap perusahan X memiliki design yang khusus dan berciri khas. Design khusus dan menarik membuat pelanggan merasa nyaman saat makan di perusahan X Jember.

Tabel 4. Analisi uji t

\begin{tabular}{lcc}
\hline \multicolumn{1}{c}{ Variabel } & $t$ & Sig. \\
\hline Harga $\left(\mathrm{X}_{1}\right)$ & -.864 & .390 \\
Cita Rasa $\left(\mathrm{X}_{2}\right)$ & 3.101 & .003 \\
Promosi $\left(\mathrm{X}_{3}\right)$ & .479 & .634 \\
Gaya Hidup $\left(\mathrm{X}_{4}\right)$ & .973 & .334 \\
Desain interior $\left(\mathrm{X}_{5}\right)$ & 5.198 & .000 \\
\hline
\end{tabular}

Tabel 5. Skor harga

\begin{tabular}{clc}
\hline No. & \multicolumn{1}{c}{ Keterangan } & Skor \\
\hline 1. & Harga yang ditawarkan sesuai dengan kualitas produk yang & 3,19 \\
& didapat & \\
2. & Menurut anda, ayam goreng memiliki harga yang terjangkau & 2,65 \\
3. & Harga produk ayam goreng dinilai ekonomis bagi pelanggan & 2,45 \\
\hline & Total & 8,29 \\
\hline & Rata-rata & 2,76 \\
\hline
\end{tabular}

\section{Variabel Harga}

Skor harga terhadap keputusan pembelian disajikan pada Tabel 5 dengan skor rata-rata sebesar 2,76 yang berarti konsumen cukup setuju terhadap harga ayam goreng di perusahaan X. Persepsi konsumen mengenai harga ayam goreng di perusahaan $\mathrm{X}$ dinilai sesuai dengan yang didapat oleh konsumen. Harga yang ditawarkan dinilai cukup terjangkau. Hal tersebut dapat dilihat dari uji regresi linear berganda (Tabel 2) pada hubungan variabel harga memiliki nilai negatif. Artinya semakin rendah nilai harga yang ditawarkan dapat meningkatkan keputusan pembelian, sebaliknya apabila nilai harga semakin tinggi nilar harga di perusahaan X dapat menurunkan keputusan pembelian. Konsumen Kabupaten Jember menilai faktor harga bukan menjadi pertimbangan utama dalam keputusan pembelian produk perusahaan $\mathrm{X}$, karena konsumen memiliki persepsi selain harga.

\section{Variabel Cita Rasa}

Skor cita rasa terhadap keputusan pembelian disajikan pada Tabel 6 dengan skor rata-rata sebesar 2,79 yang berarti konsumen cukup setuju terhadap cita rasa ayam goreng di perusahaan $X$. Konsumen menilai perusahaan $\mathrm{X}$ memiliki cita rasa ayam goreng yang khas dan dinikmati semua kalangan. Cita rasa khas menjadi salah satu faktor persepsi konsumen untuk membeli ayam goreng di perusahaan X. Hasil uji regresi linear (Tabel 2) berganda menunjukkan hubungan positif yang berarti semakin tinggi nilai cita rasa pada perusahaan X dapat meningkatkan keputusan pembelian, sebaliknya apabila nilai cita rasa terjadi penurunan maka dapat menurunkan keputusan pembelian. Cita rasa khas, konsisten, terjaga kebersihan dan mutunya membuat konsumen percaya kepada produk tersebut untuk dikonsumsi. Konsumen dengan latar belakang yang berbeda memndang bahwa cita rasa produk ayam goreng 
merupakan sebuah kebutuhan atau keinginan.

Hal tersebut didasarkan pada masing-masing konsumen yang menilai bahwa rasa yang ditawarkan menjadi favorit konsumen ketika memilih menu makanan diluar rumah. Beberapa konsumen yang menjadi responden menyatakan bahwa cita rasa ayam goreng perusahan $\mathrm{X}$ merupakan kebutuhan seharihari yang harus dipenuhi. Cita rasa produk ayam goreng menjadi sebuah kebutuhan diungkapkan utamanya oleh ibu rumah tangga yang menyatakan bahwa terdapat anggota keluarga yang memilih ayam goreng $\mathrm{X}$ untuk menu setiap harinya

Tabel 6. Skor cita rasa

\begin{tabular}{cll}
\hline No. & \multicolumn{1}{c}{ Keterangan } & Skor \\
\hline 1. & $\begin{array}{l}\text { Ayam goreng memiliki cita rasa khas bagi pelanggan yang } \\
\text { dapat memenuhi selera pelanggan }\end{array}$ & 3,12 \\
2. & $\begin{array}{l}\text { Kebersihan dan terjaganya mutu pada produk khusunya } \\
\text { pada ayam goreng } \\
\text { Ayam goreng memiliki rasa yang konsisten dari waktu ke } \\
\text { waktu }\end{array}$ & 2,61 \\
\hline \multicolumn{2}{c}{ Total } & 2,64 \\
\hline & Rerata & 8,37 \\
\hline
\end{tabular}

Tabel 7. Skor promosi

\begin{tabular}{clc}
\hline No. & \multicolumn{1}{c}{ Keterangan } & Skor \\
\hline 1. & $\begin{array}{l}\text { Ayam goreng diketahui dari periklanan media elektronik } \\
\text { (televisi,website dan pembaharuan di tempat) }\end{array}$ & 2,96 \\
2. & $\begin{array}{l}\text { Pemberian hadiah berupa VCD dan harga yang hemat pada } \\
\text { paket yang disediakan } \\
\text { Terdapat promosi dan pembaharuan informasi mengenai } \\
\text { varian baru }\end{array}$ & 2,60 \\
\hline \multicolumn{2}{c}{ Total } & 2,36 \\
\hline & Rata-rata & 7,92 \\
\hline
\end{tabular}

\section{Variabel Promosi}

Skor promosi terhadap keputusan pembelian disajikan pada Tabel 7. Hasil skor diperoleh rata-rata sebesar 2,64 yang menunjukkan bahwa konsumen cukup setuju terhadap promosi ayam goreng di perusahaan $X$. Hasil uji regresi linear berganda (Tabel 2) berganda menunjukkan hubungan positif $(+)$ yang berarti semakin tinggi nilai promosi pada perusahaan $\mathrm{X}$ dapat meningkatkan keputusan pembelian, sebaliknya apabila nilai promosi terjadi penurunan maka dapat menurunkan keputusan pembelian produk ayam goreng di perusahaan X. Hal tersebut dikarenakan konsumen secara tidak langsung sudah mengetahui produk ayam goreng yang ditawarkan di perusahaan X. Kebiasaan konsumen yang mengenal awal produk ayam goreng sudah melekat dan menjadi rutinitas untuk membeli menu tertentu yang biasa dikonsumsinya. Konsumen mengetahui bahwa pemasaran perusahaan $\mathrm{X}$ dilakukan dibeberapa media yakni televisi, website, sosial media, dan informasi langsung di tempat makan perusahaan X. Ketika proses penelitian berlangsung terdapat promosi mengenai produk varian baru dari ayam goreng perusahaan $\mathrm{X}$. Sebagian besar konsumen datang dan makan di perusahaan $\mathrm{X}$ ingin mencoba menu baru tersebut dengan alasan ingin merasakan varian baru dari perushaan X. Beberapa konsumen lain yang menjadi responden dalam penelitian ini menyampaikan bahwa konsumen datang di perushaan $\mathrm{X}$ dan memilih membeli menu yang pada umumnya dipesan yaitu ayam goreng original ukuran sedang dengan rasa khas di perusahaan X. 
Tabel 8. Skor gaya hidup

\begin{tabular}{cll}
\hline No. & \multicolumn{1}{c}{ Keterangan } & Skor \\
\hline 1. & Makan ayam goreng karena mengikuti trend yang terjadi & 3,07 \\
2aat ini & Membeli produk ayam goreng karena sangat praktis \\
3. & $\begin{array}{l}\text { Perusahaan X merupakan brand yang dipertmbangkan, } \\
\text { sehingga sebagai cerminan gaya hidup konsumen }\end{array}$ & 2,81 \\
\hline & Total & 8,71 \\
\hline
\end{tabular}

\section{Variabel Gaya Hidup}

Skor gaya hidup terhadap keputusan pembelian disajikan pada Tabel 8 dengan skor rata-rata sebesar 2,90 yang berarti konsumen cukup setuju bahwa pembelian ayam goreng di perusahaan $\mathrm{X}$ merupakan bagian dari gaya hidup. Hasil uji regresi linear berganda (Tabel 2) menunjukkan hubungan positif yang berarti semakin tinggi nilai gaya hidup pada perusahaan $\mathrm{X}$ dapat meningkatkan keputusan pembelian, sebaliknya apabila nilai gaya hidup rendah maka dapat menurunkan keputusan pembelian. Gaya hidup pada penelitian ini meliputi trend, produk praktis, dan brand yang dipertimbangkan oleh konsumen. Merek suatu produk merupakan suatu cerminan gaya hidup seseorang dalam melakukan keputusan pembelian (Liwe, 2013). Konsumen menilai bahwa membeli ayam goreng di perusahan $\mathrm{X}$ sudah menjadi kebiasaan yang dilakukan oleh konsumen khususnya Kabupaten Jember. Konsumen menilai bahwa mereka datang bukan karena gengsi ataupun terlihat modern. Ayam goreng perusahaan $\mathrm{X}$ sudah menjadi bagian gaya hidup dari konsumen Kabupaten Jember

Tabel 9. Skor desain interior

\begin{tabular}{clc}
\hline No. & \multicolumn{1}{c}{ Keterangan } & Skor \\
\hline 1. & $\begin{array}{l}\text { Memiliki desain yang unik dan berciri khas, sehingga } \\
\text { konsumen merasa nyaman ketika makan di perusahaan X }\end{array}$ & 2,95 \\
2. $\begin{array}{l}\text { Memiliki bebeapa fasilitas sesuai dengan kebutuhan } \\
\text { konsumen (tempat bermain, wifi dan kondisi yang nyaman } \\
\text { dengan pendukung air conditioner) }\end{array}$ & 2,80 \\
3. $\begin{array}{l}\text { Memiliki prosedur SOP yang dapat menjamin mutu } \\
\text { kesehatan, sehingga desain interior terjaga kebersihannya }\end{array}$ & 3,38 \\
\hline & Total & 9,13 \\
\hline & Rerata & 3,04 \\
\hline
\end{tabular}

\section{Variabel Desain Interior}

Skor desain interior terhadap keputusan pembelian disajikan pada Tabel 9., dengan skor rata-rata sebesar 3,04. Hasil uji regresi linear berganda (Tabel 2) berganda menunjukkan hubungan positif yang berarti semakin tinggi nilai desain interior pada perusahaan $\mathrm{X}$ dapat meningkatkan keputusan pembelian, sebaliknya apabila nilai desain interior rendah dapat menurunkan keputusan pembelian. erusahan $\mathrm{X}$ memiliki tata letak yang berbeda yaitu: terdapat tempat bermain untuk anak-anak, design unik, tempat luas, dan dilengkapi dengan air conditioner untuk meningkatkan kenyamanan konsumen. Konsumen menilai desain interior yang disediakan oleh perusahaan $\mathrm{X}$ sesuai dengan kebutuhan maupun keinginan konsumen. Hal ini didasari oleh seluruh konsumen dari setiap kalangan dan perbedaan pekerjaan memiliki kriteria tempat makan yang berbeda untuk menunjang kepuasannya. 


\section{KESIMPULAN}

Faktor yang menjadi pertimbangan konsumen untuk melakukan keputusan pembelian produk ayam goreng di perusahaan $\mathrm{X}$ adalah harga, cita rasa, promosi, gaya hidup, dan desain interior. Faktor dominan dalam penelitian ini adalah desain interior secara statistik memiliki nilai sangat signifikan terhadap keputusan pembel

\section{DAFTAR PUSTAKA}

Dien, H.H.M., S.G. Oroh, dan D. Soepono. 2016. Pengaruh kualitas produk, tampilan fisik dan mutu layanan terhadap loyalitas pelanggan di rumah makan ayam kuning lalapan Jogja. Jurnal Berkala Ilmiah Efisiensi. 16(2): 483-494.

Kementerian Pertanian Republik Indonesia. 2015. Produksi Daging Ayam Ras Pedaging Menurut Provinsi 2011-2015.

Kusherawati, I, S., Widayanesti, dan K.R. Siregar. 2015. The Influence of store layout and desain interiors against a purchase decision: in KFC Fast Food Bandung, Indonesia. International Journal of Science and Research. 4(4): 1625-1629.

Kotler, P. 2008. Manajemen Pemasaran. Edisi millennium. PT Prenhallindo. Jakarta.

Liwe, M. 2013. Kesadaran merek, keragaman produk dan kualitas produk pengaruhnya terhadap pengambilan keputusan konsumen membeli di KFC Manado. Jurnal EMBA. 1(4): 2107-2116.

Nilasari, D.R. 2012. Pengaruh ketidak puasan konsumen, harga dan kebutuhan mencari variasi terhadap perpindahan merek sabun lifebuoy di Semarang. Skripsi. Fakultas Ekonomika dan Bisnis. Universitas Diponegoro. Semarang.

Rahardjo, C.R. 2016. Faktor yang menjadi preferensi konsumen dalam membeli produk frozen food. Jurnal Manajemen dan Start Up Bisnis. 1(1): 32-44.

Rani, P. 2014. Factors influencing consumer behaviour. International Journal of Current Research and Academic Review. 2(9): 52-61.

SWA. 2014. Daftar Top 10 Perusahaan Restoran Fast food di Indonesia Tahun
2014. https://swa.co.id/swa/trends/inisebabnya-pelanggan-kfc-datang-

kembali. Diakses tanggal 12 Februari 2017.

Simamora. 2001. Memenangkan Pasar dengan Pemasaran Efektif dan Profitabel. PT Gramedia Pustakan Utama. Jakarta.

Sugiyono. 2014. Statistika untuk Penelitian. Alfabeta. Bandung.

Usman, Husaini, dan P.S. Akbar. 2000. Pengantar Statistika. Sinar Grafika Ofset. Jakarta. 